\title{
Foaming behavior of Ti6Al4V particle-added aluminum powder compacts
}

\author{
N. D. Karsu · S. Yüksel · M. Güden
}

Received: 27 January 2008/ Accepted: 7 October 2008/Published online: 6 November 2008

(C) Springer Science+Business Media, LLC 2008

\begin{abstract}
The foaming behavior of $5 \mathrm{wt} . \%$ Ti6Al4V (Ti64) particle $(30-200 \mu \mathrm{m})$-added $\mathrm{Al}$ powder compacts was investigated in order to assess the particle-addition effects on the foaming behavior. Al compacts without particle addition were also prepared with the same method and foamed. The expansions of Ti64 particle-added compacts were measured to be relatively low at small particle sizes and increased with increasing particle size. At highest particle size range $(160-200 \mu \mathrm{m})$, particle-added compacts showed expansion behavior similar to that of $\mathrm{Al}$ compacts without particle addition, but with lower expansion values. Expansions studies on 30-45 $\mu \mathrm{m}$ size Ti64-added compacts with varying weight percentages showed that the expansion behavior of the compacts became very similar to that of $\mathrm{Al}$ compact when the particle content was lower than 2 wt.\%. However, Ti64 addition reduced the extent of drainage. Ti64 particles and $\mathrm{TiAl}_{3}$ particles formed during foaming increased the apparent viscosity of the liquid foam and hence reduced the flow of liquid metal from cell walls to plateau borders. The reduced foamability in the compacts with the smaller size Ti64 addition was attributed to the relatively high viscosities, due to the higher cumulative surface area of the particles and higher rate of $\mathrm{TiAl}_{3}$ formation between liquid $\mathrm{Al}$ and Ti64 particles.
\end{abstract}

N. D. Karsu · S. Yüksel · M. Güden ( $\square)$

Department of Mechanical Engineering, İzmir Institute

of Technology, Gulbahce Köyu, Urla, Izmir, Turkey

e-mail: mustafaguden@iyte.edu.tr

M. Güden

Center for Materials Research, İzmir Institute of Technology,

Gulbahce Köyu, Urla, Izmir, Turkey

\section{Introduction}

$\mathrm{Al}$ closed-cell foams are currently manufactured by several different processes, in which the foam is stabilized by particle addition into the liquid metal either in situ or ex situ. In Cymat foam, the liquid metal is foamed by gas injection (e.g., air or nitrogen) into the melt and the liquid foam is stabilized by adding $8-20 \mu \mathrm{m}$ size $\mathrm{SiC}$ particles [1]. The foam stability was shown to be a function of particle volume fraction and the distance traveled by the bubbles [2]. At low traveling distances and low $\mathrm{SiC}$ volume contents, the bubbles burst and the stability was lost, while the stability increased at long traveling distances and high volume content of $\mathrm{SiC}$ particles. Cell sizes and cell wall thicknesses increased with increasing particle size and particle volume fractions, while the cell wall thicknesses decreased with increasing foaming temperature [3]. The presence of particles in liquid foam increased the bulk viscosity of the composite melt and, hence, reduced the liquid flow from cell faces to cell edges. The particles at liquid/gas interface further reduced the capillary pressure difference between cell edge and cell wall. Both were noted to be effective in the stability of the composite foam [3]. The effects of Al melt viscosity, which is adjusted by the $\mathrm{Ca}$ addition, the melt stirring time, and the furnace holding time, on the cell structure of Alporas foams were studied by Song et al. [4]. The metal foam stability increased and the cell size decreased with increasing melt viscosity. It was further emphasized that too high viscosity might prevent the homogenous dispersion of the foaming agent. Larger cell sizes formed at increasing furnace holding times and decreasing wt.\% of the foaming agent. In foaming of powder compact process, foam stabilization was ascribed to the metal oxide filaments, which are the remnants of the thin oxide layer on the aluminum powders and/or the solid 
component of the particular alloy (Al-rich phase in the AlSi eutectic) [5]. The effect of oxygen content of the starting Al powder on the expansion and stability of $\mathrm{Al}-0.6 \% \mathrm{TiH}_{2}$ powder compacts was investigated by Asavavisithchai and Kennedy [6]. The oxide content of the powder was increased by the pre-heat treatment process applied to the powder before the consolidation. It was shown that the maximum foam expansion increased with increasing oxygen content, up to 0.333 wt. $\%$, while increasing oxygen content above 0.6 wt.\% resulted in relatively low expansions but more stable foams. The oxide particles formed clusters of crumpled films, restricting the drainage. It has been recently shown that non-wetted $\mathrm{TiB}_{2}$ addition to $\mathrm{Al}$ powder compacts in the foaming of powder compact process, although increasing the plateau stresses, was not effective in long-term foam stabilization [7]. Contrary to $\mathrm{TiB}_{2}$ addition, $\mathrm{SiC}_{\mathrm{p}}$ addition of 3 and $10 \mathrm{wt}$. $\%$ was shown to improve the foam stability of $\mathrm{Al}$ powder compacts [8, 9]. Babcsan et al. [10,11] analyzed the stability of Al metal foaming processes ex situ and in situ. In foams of $13 \mu \mathrm{m}$ $\mathrm{SiC}$ particles, the particles were observed to segregate to the cell wall surfaces, while in foams of $70 \mu \mathrm{m} \mathrm{SiC} \mathrm{particles,}$ only small amount of particles were observed on the cell wall surfaces. The cell wall thicknesses were also found to be quite different: $85-100 \mu \mathrm{m}$ in foams of $13 \mu \mathrm{m}$ size $\mathrm{SiC}$ particles and up to $300 \mu \mathrm{m}$ in foams of $70 \mu \mathrm{m}$ size $\mathrm{SiC}$ particles.

The present report is a further investigation of the effect of particle addition on the foaming behavior of $\mathrm{Al}$ powder compacts used in the foaming of powder compact process. For that purpose, Ti6Al4V (Ti64)-Al composite and $\mathrm{Al}$ powder compacts were prepared and foamed. Ti64 are known to be wetted by liquid $\mathrm{Al}$ and therefore a good model particle to see the effect of wetted particles on the expansion of Al powder compacts. The effect of Ti64 addition on the foaming behavior was determined by comparing the expansions of $\mathrm{Al}$ compacts processed under the same conditions.

\section{Experimental}

The average particle size of $\mathrm{Al}$ powder was $34.64 \mu \mathrm{m}$ and the size of $\mathrm{TiH}_{2}$ particles was less than $37 \mu \mathrm{m}$. Ti64 powder was manufactured by Phelly Materials Company, with a particle size range of 30-200 $\mu \mathrm{m}$. The particles were spherical in shape and the microstructure consisted of acicular needle-like alpha $(\alpha)$, which is known as martensitic $\alpha$. The powder was sieved to particle size ranges 30-45, 45-56, 56-90, 90-106, 106-160, and 160-200 $\mu \mathrm{m}$ to determine the effect of Ti64 particle size on the foaming behavior of $\mathrm{Al}$ compacts.

The foam preparation process started with the mixing of appropriate amounts of basic ingredients. Compacts with a diameter of $30 \mathrm{~mm}$ and a thickness of $\sim 8 \mathrm{~mm}$ were prepared by cold compaction inside a stainless steel die under varying pressures to reach a relative density near $98 \%$. To assess the effect of Ti64 powder addition on the foaming, Al compacts without Ti64 addition were also prepared and foamed under the same conditions. A higher compaction pressure was applied in the compaction of particle containing powder mixtures to increase the relative densities to the levels of $\mathrm{Al}$ compacts without particle addition. The mean relative density was around $97 \%$ for $\mathrm{Al}$ compacts with particle addition and $98 \%$ for $\mathrm{Al}$ compacts without particle addition as tabulated in Table 1. In all foamed compacts, $\mathrm{TiH}_{2}$ content was held constant, 1 wt.\%.

The schematic presentation and front view of the foaming setup used in the foam expansion measurements are shown in Fig. 1a, b, respectively. The experimental setup consists of a vertical split furnace, a linear expansion measurement system, and a foaming mold, which accommodates the compact. The bottom of the foaming mold ( $3 \mathrm{~cm}$ in diameter and $8 \mathrm{~cm}$ in height) was closed tightly and the compact was inserted at the bottom. The linear expansion measuring system consists of a linear variable displacement transducer (LVDT), a wire which is connected to the expansion steel rod and pulleys. In a typical experiment, the furnace was initially heated to $750{ }^{\circ} \mathrm{C}$. The mold accommodating the compact was then inserted into the furnace with the help of an elevator. The rod connected to linear expansion measuring system was lowered and the steel plate attached to the end of the rod contacted the compact upper surface. As soon as the mold was inserted, the furnace temperature decreased to $600{ }^{\circ} \mathrm{C}$. The furnace temperature rose to $730{ }^{\circ} \mathrm{C}$ within $10 \mathrm{~min}$ as the mold was heated up. The expansion of the compact moved the linear expansion measuring wire to backward with the help of two pulleys as shown in Fig. 1b. The measurements were taken with a data logger that was directly connected to the

Table 1 Relative density of the compacts

\begin{tabular}{lllllllll}
\hline & Al & $\begin{array}{l}(30-45 \mu \mathrm{m}) \\
5 \text { wt.\% }\end{array}$ & $\begin{array}{l}(30-45 \mu \mathrm{m}) \\
1 \text { wt.\% }\end{array}$ & $\begin{array}{l}(45-56 \mu \mathrm{m}) \\
5 \text { wt.\% }\end{array}$ & $\begin{array}{l}(56-90 \mu \mathrm{m}) \\
5 \text { wt.\% }\end{array}$ & $\begin{array}{l}(90-106 \mu \mathrm{m}) \\
5 \text { wt. \% }\end{array}$ & $\begin{array}{l}(106-160 \mu \mathrm{m}) \\
5 \text { wt. \% }\end{array}$ & $\begin{array}{l}(160-200 \mu \mathrm{m}) \\
5 \text { wt.\% }\end{array}$ \\
\hline Minimum & 97.59 & 96.69 & 96.90 & 96.80 & 96.90 & 96.90 & 96.80 & 96.69 \\
Maximum & 98.69 & 96.80 & 97.40 & 97.40 & 97.09 & 97 & 97 & 97.40 \\
Mean & 98.01 & 96.77 & 97.13 & 96.97 & 97.03 & 96.96 & 96.87 & 97.04 \\
\hline
\end{tabular}



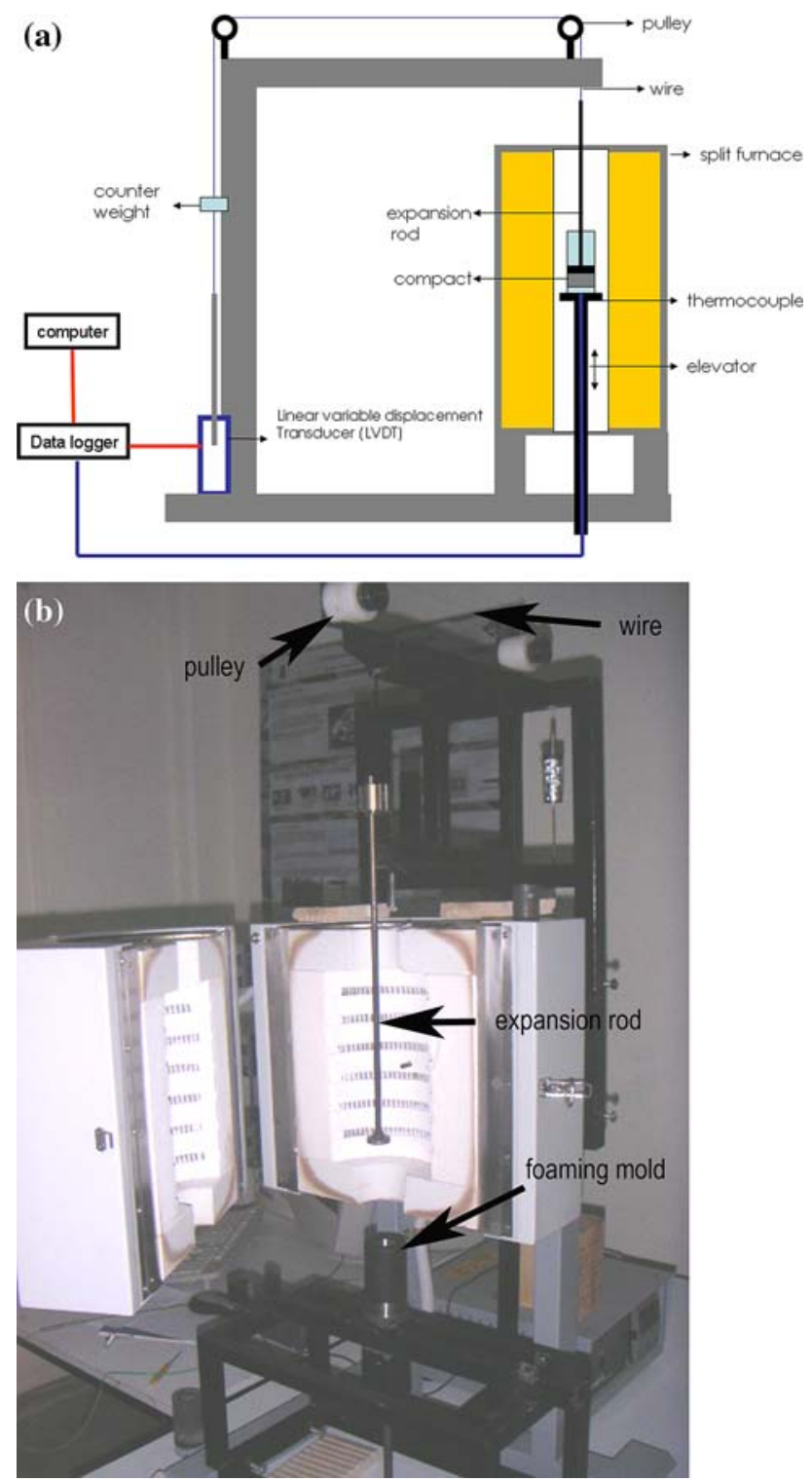

Fig. 1 a Schematic and $\mathbf{b}$ the front view of foam expansionmeasurement setup

LVDT. The linear expansion data ( $\mathrm{mm})$ was then converted to linear expansion (LE) using the following equation:

$\mathrm{LE}=\frac{\text { Expansion }}{\text { Initial length }}$

Two types of measurements were made in the foaming experiments. In the first, the compacts were foamed for 10 $15 \mathrm{~min}$ and cooled at room temperature. In the second, the compacts were foamed at various furnace holding times such as 100, 150, 200, 300, 400, and $500 \mathrm{~s}$ and then taken from the furnace quickly and then quenched in water (interrupted foaming tests). The foaming mold prevented the liquid foam from contacting the water. Each procedure took $10-15 \mathrm{~s}$ to move the compacts from the furnace and quench in water. Therefore, the microstructure of the quenched foams showed the foam structure with a delay of $10-15 \mathrm{~s}$.

Various kinds of microscopic analysis techniques were applied to the foamed compacts. To prevent cells from getting damaged, the foams were sectioned parallel to the expansion direction using an electrical discharge machine. The cross sections were then ground and polished gently for microscopic analysis. The polished cross sections were etched before microscopic analyses using Kroll's reagent $\left(3 \mathrm{~cm}^{3}\right.$ of $\mathrm{HF}$ and $6 \mathrm{~cm}^{3}$ of $\mathrm{HNO}_{3}$ in $100 \mathrm{~mL}$ of $\mathrm{H}_{2} \mathrm{O}$ ). Microscopic analyses were performed using a Philips XL30-SFEG scanning electron microscope (SEM) with an EDX analyzer. An image analyzing software was used in the cell size measurements on the micrographs of the foam samples.

\section{Results}

Typical linear expansion-time and temperature-time graphs of a foamed $\mathrm{Al}$ powder compact are shown in Fig. 2a. The expansion-time curve consists of 4 different regions as marked in Fig. 2a. The foam expansions are initially rather quick and increase almost linearly with time in the first and second regions. The transition from Region 1 to Region 2 occurs roughly at $125 \mathrm{~s}$ and $673{ }^{\circ} \mathrm{C}$ (marked with arrow in Fig. 2a). The expansion reaches a maximum value $\left(\mathrm{LE}_{\max }\right)$ in $147-169 \mathrm{~s}$. Following the maximum expansion, the expansion decreases in Region 3. In Region 4, the expansion is nearly constant and labeled as LE (Fig. 2a). During foaming experiments, although the furnace temperature is held at $750{ }^{\circ} \mathrm{C}$, when the cold steel mold accommodating the foamable compact is inserted, the furnace temperature decreases to $600{ }^{\circ} \mathrm{C}$. After compact insertion, the temperature of the compact rises to $730{ }^{\circ} \mathrm{C}$ as depicted in Fig. 2a. $\mathrm{LE}_{\max }$ and $\mathrm{LE}$ values of $\mathrm{Al}$ compacts vary between 4.13 and 4.86 and between 3.25 and 3.86, respectively (Fig. 2b). The ex situ measured expansion values of the studied $\mathrm{Al}$ compacts (expansion was calculated from the final length of the foamed compacts) are also shown in the same figure and show very similar expansion values with those of in situ measurements. Discrepancies may naturally arise because of the shrinkage of the foam during solidification in ex situ measurements.

Expansion-time graphs of 5 wt.\% 30-45, 90-106, 106160, and 160-200 $\mu \mathrm{m}$ size Ti64-Al powder compacts are sequentially shown in Fig. 3a-d. The addition of 5 wt.\% 30-45 $\mu \mathrm{m}$ size Ti64 powder greatly reduces the $\mathrm{LE}_{\max }$ and LE values of particle-added compacts as compared with $\mathrm{Al}$ compacts without particle addition. The values of $\mathrm{LE}_{\max }$ range between 2.15 and 2.60, while LE is relatively low and about 1.274 as shown in Fig. 3a. Following Region 1, 

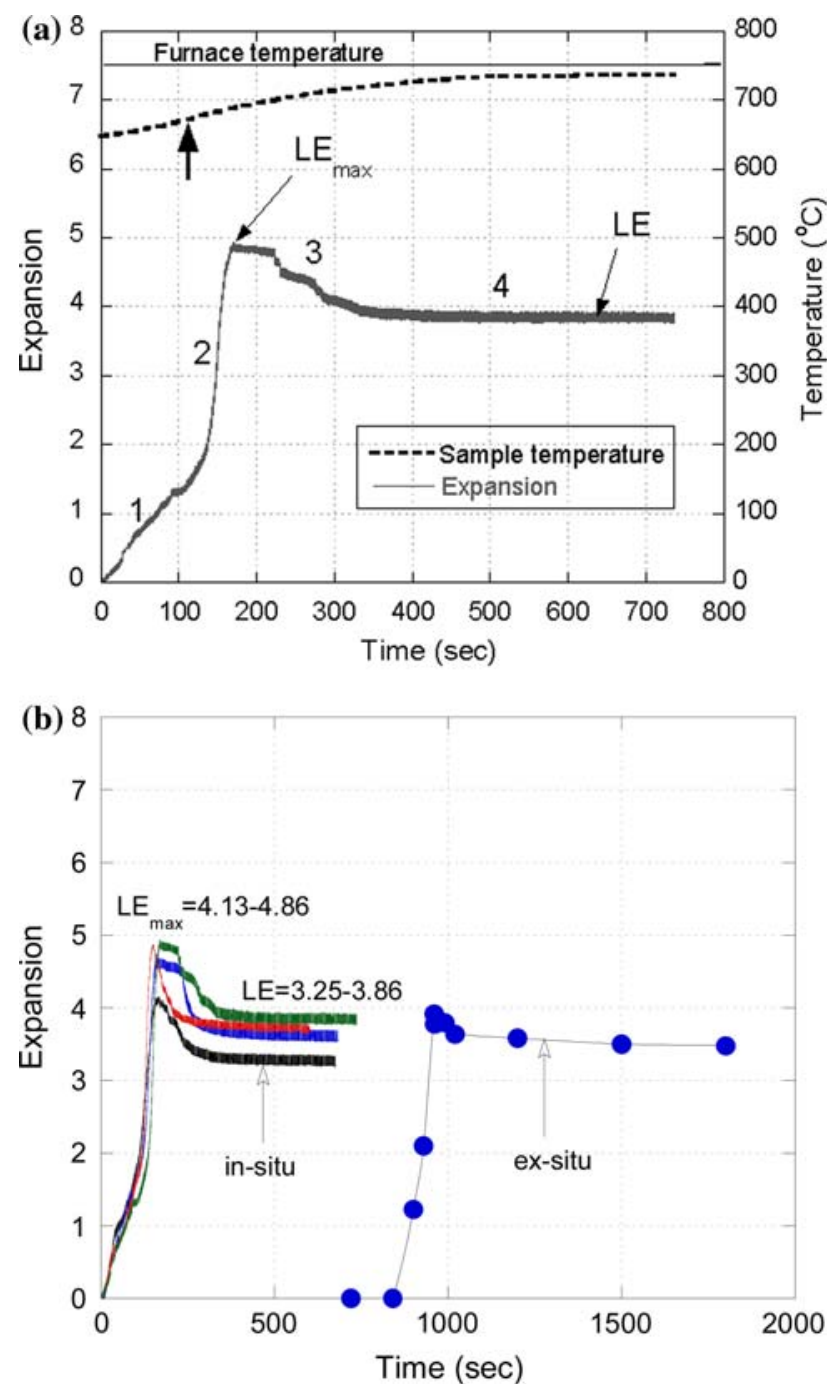

Fig. 2 a Typical expansion-time and temperature-time graphs of Al compact and b comparison of in situ and ex situ expansion measurements of $\mathrm{Al}$ compacts

the graphs show fluctuations in expansion values and the extent of fluctuations decreases at increasing furnace holding times. The addition of $5 \mathrm{wt} . \% 45-56 \mu \mathrm{m}$ size Ti64 particles resulted in $\mathrm{LE}_{\max }$ and $\mathrm{LE}$ values ranging between 2 and 3 and between 1 and 1.5, respectively. The final expansions in these compacts were also found to be very low, around 1. $\mathrm{LE}_{\max }$ and LE values in 5 wt.\% 56-90 $\mu \mathrm{m}$ size Ti64 powder compacts are also very low, around 1 and 2 , respectively as shown in Fig. 3b. In 90-106 $\mu \mathrm{m}$ size Ti64-Al powder compacts, the expansions were around $1.5-2$ at above $150 \mathrm{~s}$ and decreased gradually to 1 ; thereafter it increased to a value above 2 . The expansions in 106-160 $\mu \mathrm{m}$ size Ti64-Al powder compacts are relatively high, $2.5-3$ at above $150 \mathrm{~s}$; it gradually decreases to 2 after $150 \mathrm{~s}$; thereafter it gradually increases to a value above 2 at $800 \mathrm{~s}$ furnace holding time (Fig. 3c). The expansion behavior of 5 wt. $\%$ 160-200 $\mu \mathrm{m}$ size Ti64-Al powder compacts is however very similar to that of $\mathrm{Al}$ compacts. Regions 1 and 2 are clearly seen in the initial region of the expansion curve as shown in Fig. 3d. $\mathrm{LE}_{\max }$ and LE values vary between 3 and 3.92 and between 2.18 and 2.46, respectively. These values are lower than those of $\mathrm{Al}$ compacts, 4.13-4.86 and 3.25-3.86. It is further noted that the compacts reach maximum expansions within 80-100 s, earlier than $\mathrm{Al}$ compacts. The representative expansiontime graphs of $5 \mathrm{wt} . \%$ Ti64-Al powder compacts are shown in Fig. 4 together with that of $\mathrm{Al}$ compact for comparison. Increasing particle size at constant weight percentage of the particles increases the expansion values, while the expansion values of compacts with particle addition are lower than those of pure $\mathrm{Al}$ compacts as shown in Fig. 4. It is also noted in the same figure that the fluctuations in LE values disappear for the particles addition with sizes of or larger than 56-90 $\mu \mathrm{m}$.

To see the effect of particle weight fraction on the expansion behavior of Al compacts, 30-45 $\mu \mathrm{m}$ size Ti64$\mathrm{Al}$ powder compacts having Ti64 particle wt.\% of $0.5,1,2$, 3 , and 4 and similar relative densities were prepared and foamed in the furnace with the same processing parameters. The expansion-time graphs of the compacts of varying weight percents are shown in Fig. 5. The expansion behaviors of 0.5 and 1 wt.\% Ti64 powder-added Al compacts are very much comparable with that of $\mathrm{Al}$ compacts as seen in the same figure. However, the expansion decreases sharply when Ti64 powder weight percent increases above $1 \mathrm{wt} . \%$.

Figure 6a, b shows the general and cross-sectional views of the Al foam samples taken from the furnace after a certain furnace holding time, respectively. The final heights of the foam samples in these figures confirm clearly that the linear expansion increases until the maximum expansion (until about $150 \mathrm{~s}$ ). Cell size increases as the furnace holding time increases; particularly cells become larger at the upper sections of the foam cylinders. The drainage, the accumulation of $\mathrm{Al}$ metal at the bottom of foamed compacts, is clearly seen to increase as the furnace holding time increases (Fig. 6b). Another effect of longer furnace holding times is the thickening of the cell walls and cell edges located at the bottom sections and the cell collapse at the upper sections of the foam cylinder. In addition, increasing furnace holding times induces a non-homogenous cell size distribution in the foam cylinder. Figure 7a, $\mathrm{b}$ shows the general and cross-sectional views of the foamed $5 \mathrm{wt} . \% 160-200 \mu \mathrm{m}$ size Ti64-Al powder compacts with various furnace holding times, respectively. The initial high expansion of the compact at about $100 \mathrm{~s}$ is clearly seen in Fig. 7a. The drainage in these compacts is greatly reduced at longer furnace holding times as compared with $\mathrm{Al}$ compacts as seen in Fig. 7b. It is also noted that the initial nearly equiaxed cells are slightly elongated 
Fig. 3 Expansion-time graphs of a 30-45, b 56-90, c 106-160, and d 160-200 $\mu \mathrm{m}$ size Ti64$\mathrm{Al}$ compacts
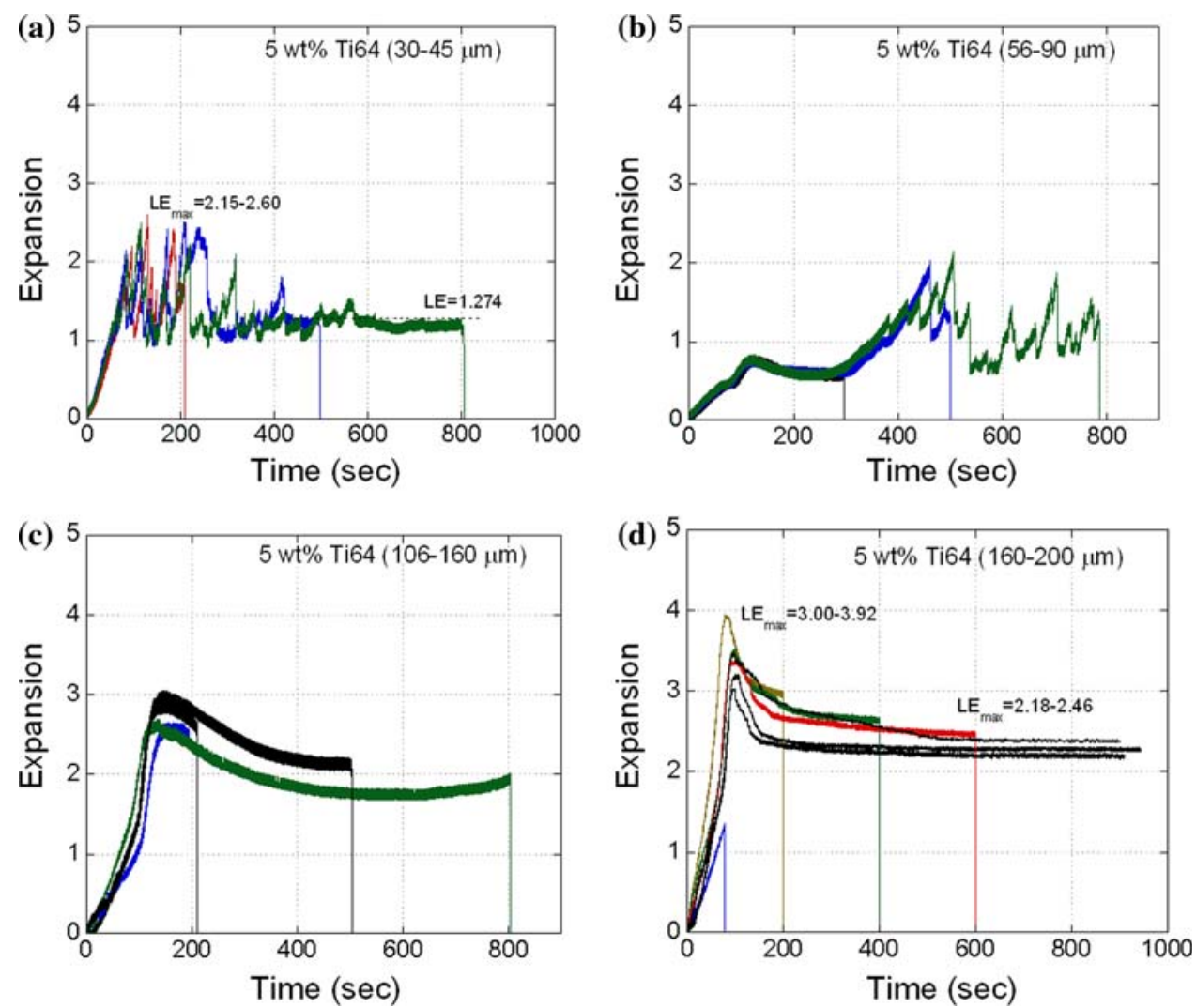

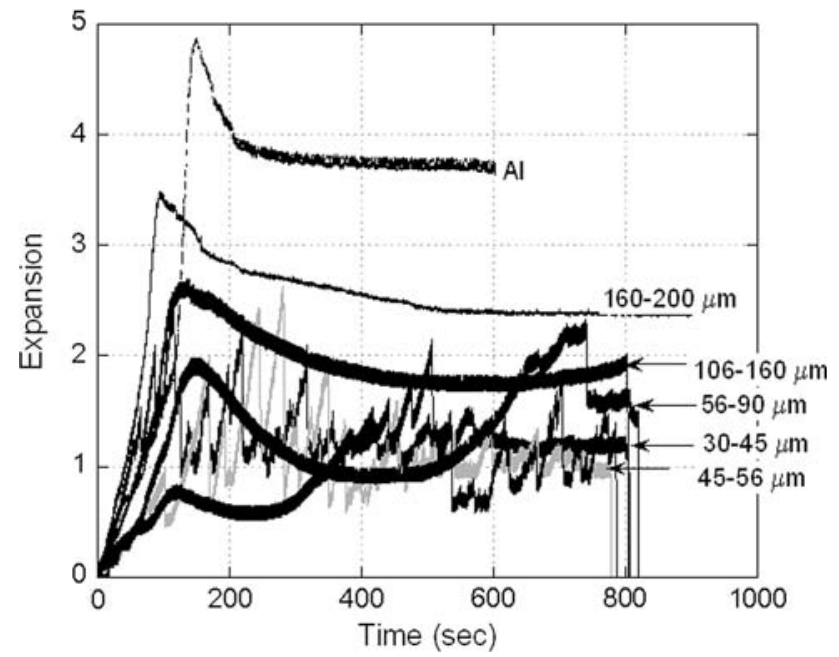

Fig. 4 Typical expansion-time graphs of 5 wt.\% Ti64-Al and Al compacts

normal to compaction direction at longer furnace holding times. Figure $8 \mathrm{a}, \mathrm{b}$ shows the cell structures of foamed $\mathrm{Al}$ and Ti64-Al compacts after furnace holding times of about 200 and $500 \mathrm{~s}$, respectively. At both furnace holding times, 200 and $500 \mathrm{~s}$, the foams of $160-200 \mu \mathrm{m}$ size Ti64-Al compacts show more homogenous cell size distribution than the foams of $\mathrm{Al}$ compacts. The reduced extent of drainage is also seen in 106-160 and $160-200 \mu \mathrm{m}$ size

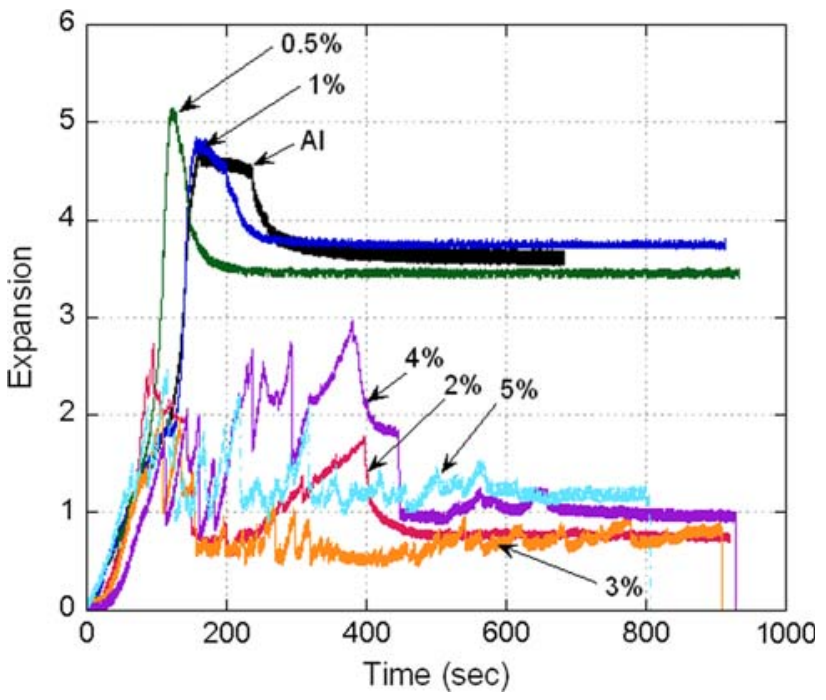

Fig. 5 Expansion-time graphs of $\mathrm{Al}$ compacts containing different wt.\% of 30-45 $\mu \mathrm{m}$ size Ti64 powder

Ti64-Al compacts as compared with Al compacts. However, the expansions in Ti64 particle-added foamed compacts are relatively low as compared with $\mathrm{Al}$ compact.

The number of cells and the cell sizes (diameters) of the foamed compacts taken from the furnace after prescribed holding times were measured using Scion Image analyzer program. For comparison, the cell sizes were measured 
Fig. 6 Pictures of foamed $\mathrm{Al}$ compact samples at various furnace holding times; a general view and $\mathbf{b}$ cross-sectional view
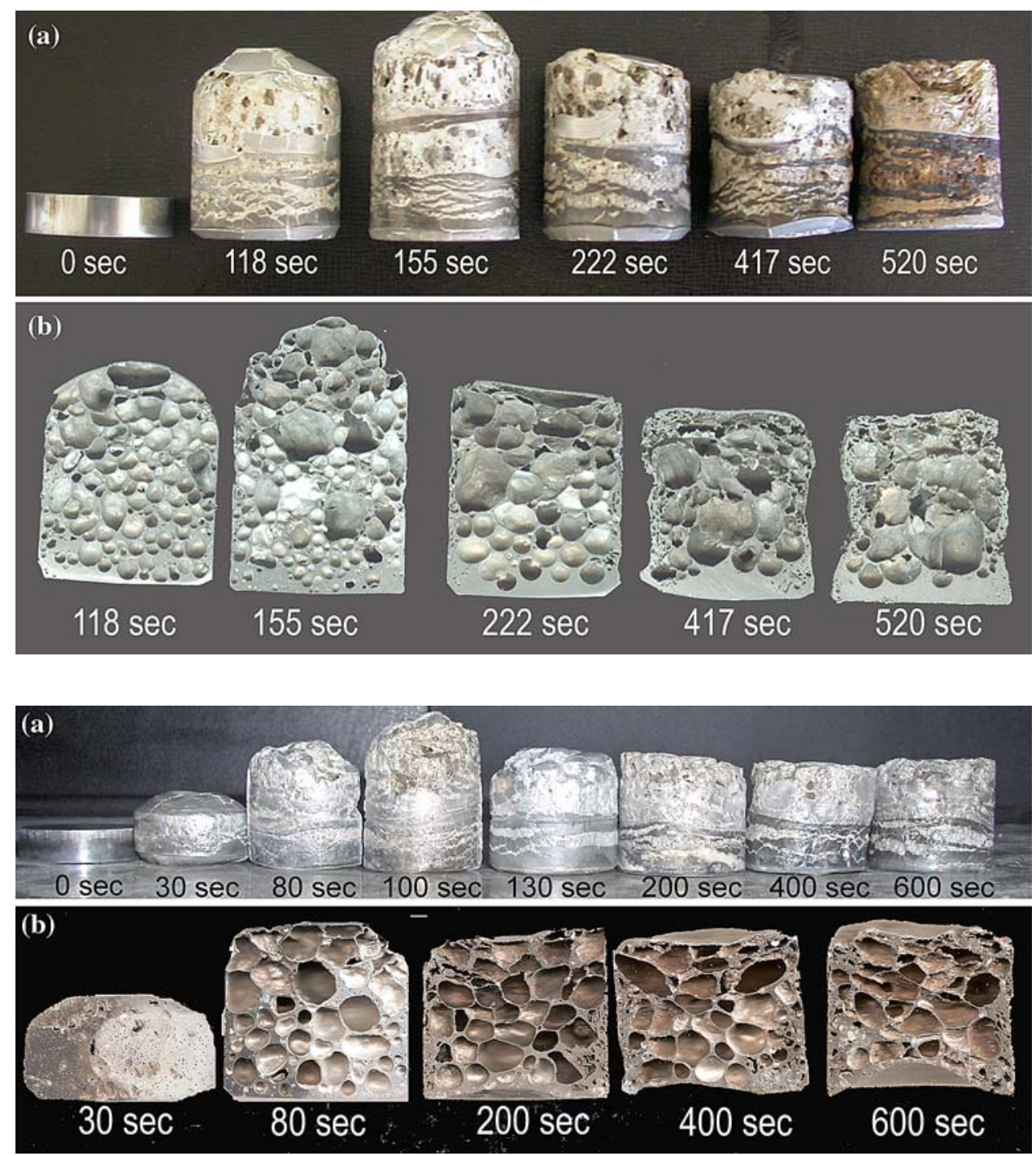

(a)

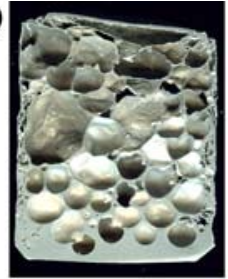

Al

(b)

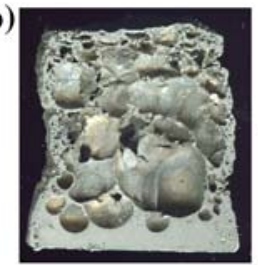

Al

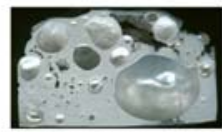

Ti64 30-45 $\mu \mathrm{m}$

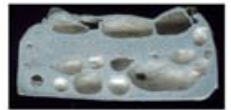

Ti64 90-106 $\mu \mathrm{m}$

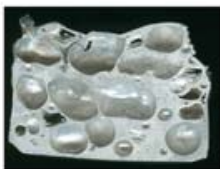

Ti64 106-160 $\mu \mathrm{m}$

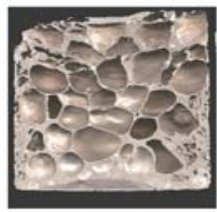

Ti64 106-200 $\mu \mathrm{m}$

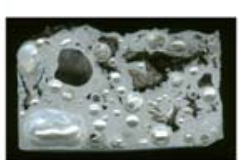

Ti64 30-45 $\mu \mathrm{m}$

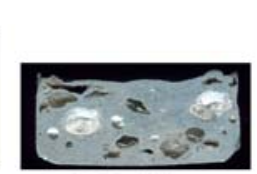

Ti64 90-106 $\mu \mathrm{m}$

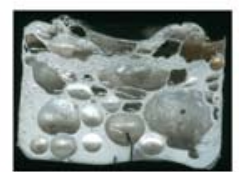

Ti64 106-160 $\mu \mathrm{m}$

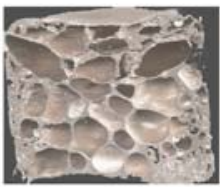

Ti64 106-200 $\mu \mathrm{m}$ horizontally as shown in Fig. 9a, b. The variation of average cell diameters and number of cells of $\mathrm{Al}$ and 160$200 \mu \mathrm{m}$ size Ti64-Al foamed compact samples are shown as a function of furnace holding time in Fig. 10. Initially, the number of cells is higher in $\mathrm{Al}$ compacts and decreases below that of $160-200 \mu \mathrm{m}$ size Ti64-Al compacts as the 
Fig. 9 Examples for the cell size measurements in $\mathbf{a} \mathrm{Al}$ and $\mathbf{b}$ 160-200 $\mu \mathrm{m}$ Ti64-Al foam samples
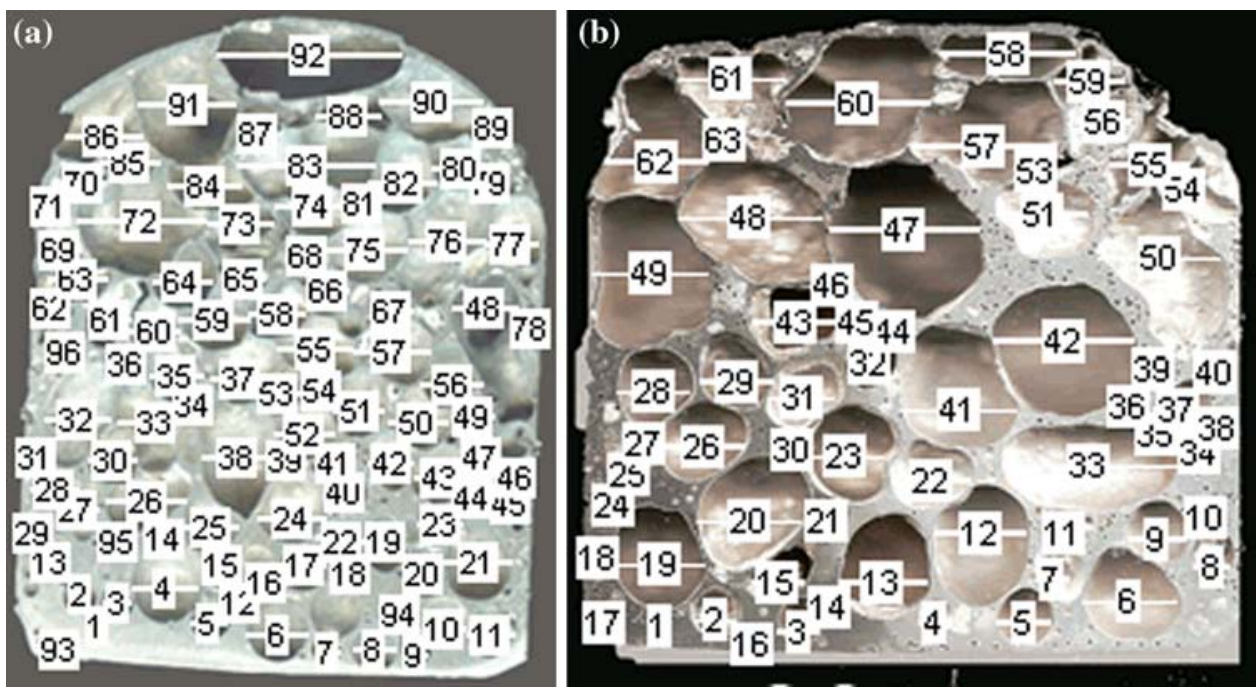

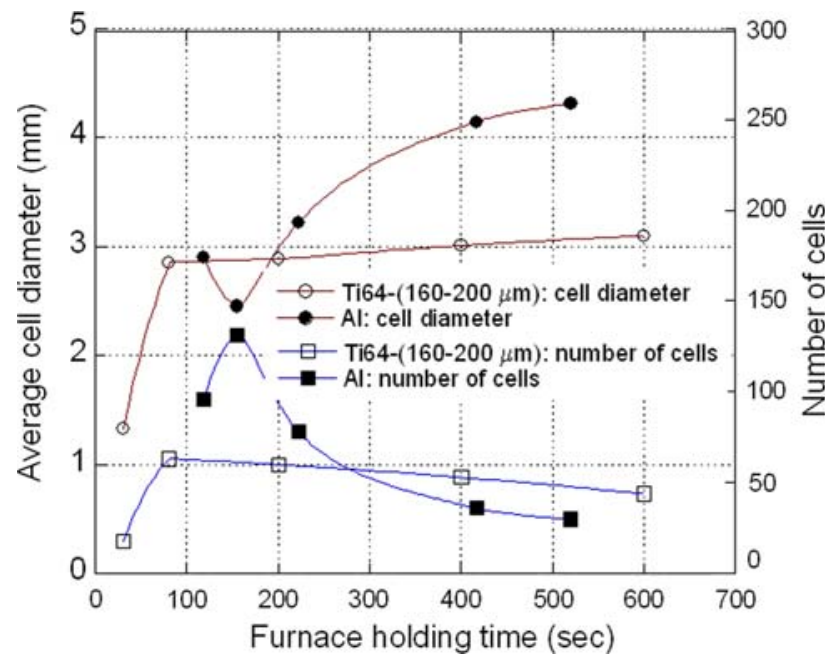

Fig. 10 Average cell diameter and number of cells vs. furnace holding time of $\mathrm{Al}$ and $160-200 \mu \mathrm{m}$ Ti64-Al foamed compact samples

furnace holding time increases. In 160-200 $\mu \mathrm{m}$ size Ti64Al compacts, the increase in the average cell diameter and decrease in the number of cells are more gradual than those in Al compacts, showing increased kinetic stability of Ti64-added foamed compacts.

During foaming, Ti64 particles reacted with liquid $\mathrm{Al}$ and formed a reaction layer. Figure $11 \mathrm{a}-\mathrm{c}$ shows the reaction layers around Ti64 particles in 160-200 $\mu \mathrm{m}$ size Ti64 particle-added foams at furnace holding times of 100 , 200 , and $600 \mathrm{~s}$, respectively. The thickness of reaction layer increases with increasing furnace holding time, from $3 \mu \mathrm{m}$ at $100 \mathrm{~s}$ to $6 \mu \mathrm{m}$ at 200 and to $15 \mu \mathrm{m}$ at $600 \mathrm{~s}$. The XRD spectrum shown in Fig. 12 shows the presence of $\mathrm{TiAl}_{3}$ intermetallic compound in the foamed compacts. Figure 13a, b shows SEM line-scan measurement next to a $\mathrm{Ti} 64$ particle and the corresponding $\mathrm{Ti}$ and $\mathrm{Al}$ variation as a function of distance in $1 \mathrm{wt} . \% \quad 30-45 \mu \mathrm{m}$ size Ti64 particle-added foam at a furnace holding time of $900 \mathrm{~s}$, respectively. The constant wt.\% of $\mathrm{Al}$ in the reaction layer in Fig. 13b proves again $\mathrm{TiAl}_{3}$ particle formation. In Fig. 14, the expansion-time graph of 5 wt. $\% 30-45 \mu \mathrm{m}$ size Ti64-Al compact is shown together with SEM pictures of cell walls at 200, 400, and $800 \mathrm{~s}$ furnace holding times. It is noted in the same figure that as the furnace holding time increases, the amount of $\mathrm{TiAl}_{3}$ particles increases. These particles are merely found in the cell walls and cell edges. At increasing amount of particle formations, the extent of fluctuations in the expansion-time graph decreases and after $600 \mathrm{~s}$ the expansion becomes steady (Fig. 14c). A general microscopic observation is that when Ti64 particles are relatively small, $\mathrm{TiAl}_{3}$ particles disperse throughout the matrix (Fig. 15a), while at increasing Ti64 particle sizes, $\mathrm{TiAl}_{3}$ particles pretty much remain connected to Ti64 particles (Fig. 15b). Larger $\mathrm{TiAl}_{3}$ particles are formed in the compacts with smaller Ti64 particles than those with larger particles.

The cross sections of $\mathrm{Al}$ and $160-200 \mu \mathrm{m}$ size Ti64-Al foamed compacts at $200 \mathrm{~s}$ furnace holding time are shown in Fig. 16a-d, respectively. In Fig. 16a, c shows the cell structure at the bottom, while (b) and (d) show the upper sections of the foam cylinders. The cell edges at the bottom of the foam cylinders (marked by arrows in Fig. 16a, c) are thicker in $\mathrm{Al}$ foam than particle-added foam, while the cell walls become thicker in particle-added foam at the mid and top sections (Fig. 16b, d). Another noticeable feature of the particle-added foams is that the particle concentration is higher at the top sections (Fig. 16d) than the bottom sections. Observations made from the cell walls further show that Ti64 particles are completely wetted by liquid Al. The particles are further found in the cell edges (Fig. 17a) and cell walls (Fig. 17b). 
Fig. 11 SEM pictures of 160$200 \mu \mathrm{m}$ size (5 wt.\%) Ti64-Al foamed compacts at furnace holding times of a 100, b 200, and $\mathbf{c} 600 \mathrm{~s}$
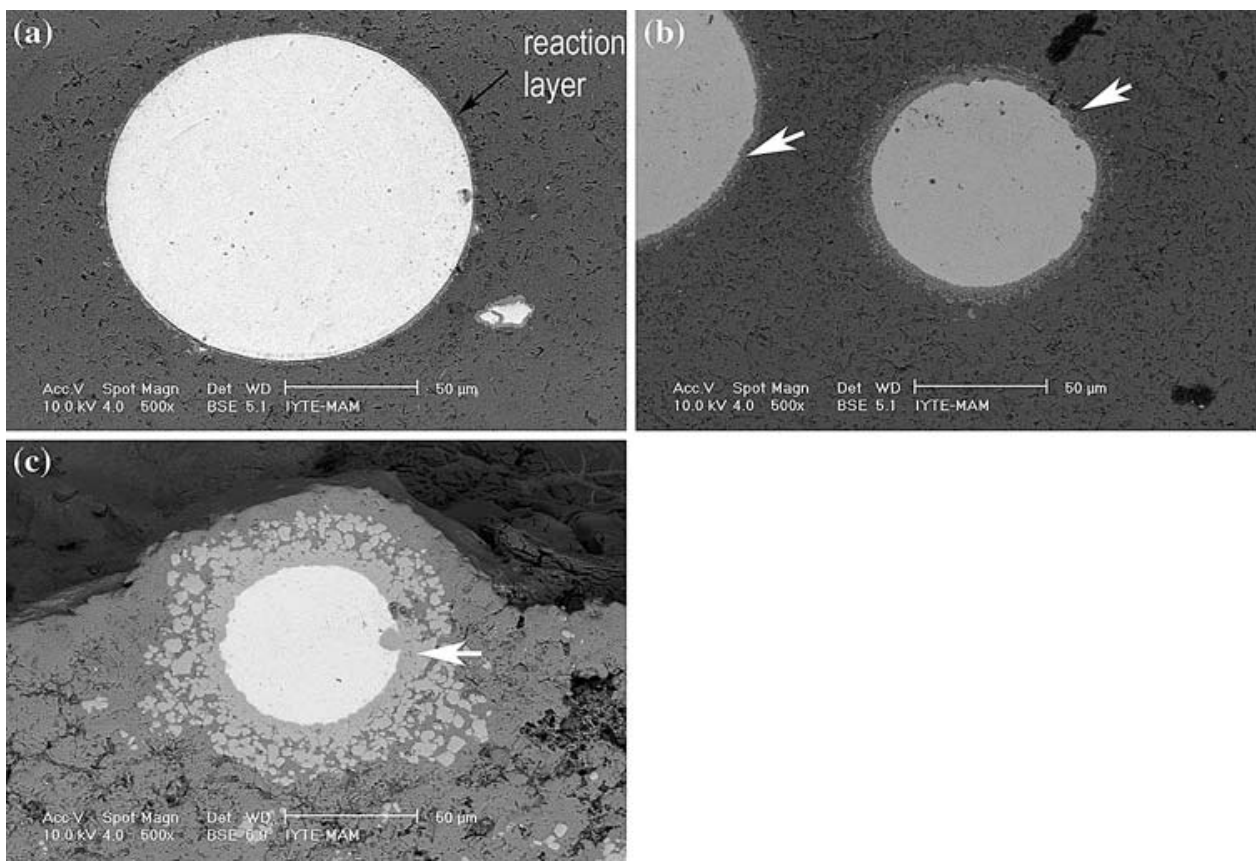

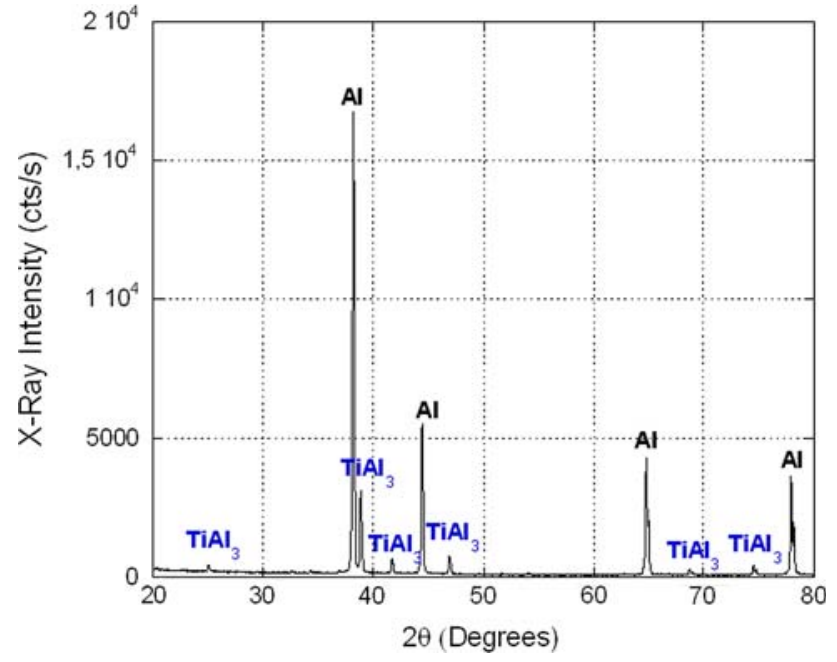

Fig. 12 XRD spectrum of a 5 wt.\% 160-200 $\mu \mathrm{m}$ Ti64-Al foamed compact sample after furnace holding time of $600 \mathrm{~s}$

\section{Discussion}

Two foaming processes starting with the same compact geometry and composition and the foaming condition would not give the same foam expansion [12]. The variations in blowing agent distribution, composition, and compaction pressure; the presence of any impurity in the compact; small variations in the heat transfer between the mold and the furnace; and the variations in the frictional forces of the expansion measurement system unavoidably lead to variations in foam expansions in between similar compacts. This effect was clearly detected in the present study.
The effects of the compaction and foaming conditions on the foaming behavior of $\mathrm{AlSi} 7$ and $6061 \mathrm{Al}$ compacts were previously studied [12, 13]. It was found that increasing the foaming temperature increased the foam expansions in both compacts within the studied temperature range of $600-800{ }^{\circ} \mathrm{C}$. Increasing the temperature reduced the viscosity and promoted the gas evolutions, leading to increased foam expansions. It was shown in the same studies that the volume expansions were saturated at $750{ }^{\circ} \mathrm{C}$ for AlSi7 alloy compact, while the viscosity of $6061 \mathrm{Al}$ alloy compact was not sufficient for efficient foaming until about $800{ }^{\circ} \mathrm{C}$. For the studied $\mathrm{Al}$ compacts, the foaming temperature was held between 700 and $730{ }^{\circ} \mathrm{C}$ and the maximum expansions were found to vary between 4.13 and 4.86. The expansion values of the studied $\mathrm{Al}$ compacts were further converted into $\mathrm{mm}$ unit for comparison with previous studies. In the present study, $8 \mathrm{~mm}$ thick Al compacts showed maximum expansions varying between 32 and $39 \mathrm{~mm}$, while the expansion values of $9 \mathrm{~mm}$ AlSi7 compacts were found to be around $45 \mathrm{~mm}$ [5]. In another study, the maximum expansion of $\mathrm{Al}$ compacts, compacted at room temperature, was found to vary between 3.5 and 4 [14]. These expansion values are comparable with the expansion values of the studied $\mathrm{Al}$ compacts. The effect of compaction method on the expansion of $\mathrm{Al}-0.6 \% \mathrm{TiH}_{2}$ powder compacts was further investigated by Asavavisithchai et al. [14]. It was shown that the simple cold-compacted $\mathrm{Al}$ powder compacts of 99\% dense produced the foam expansions similar to the ones prepared by hot compaction. 
Fig. 13 SEM line-scanning of the reaction layer in 160 $200 \mu \mathrm{m}(5 \mathrm{wt} . \%)$ Ti64 particleadded foamed compact sample $600 \mathrm{~s}$; a line segment on the reaction layer and $\mathbf{b}$ variation of the composition with respect to the distance on the reaction layer with furnace holding time of

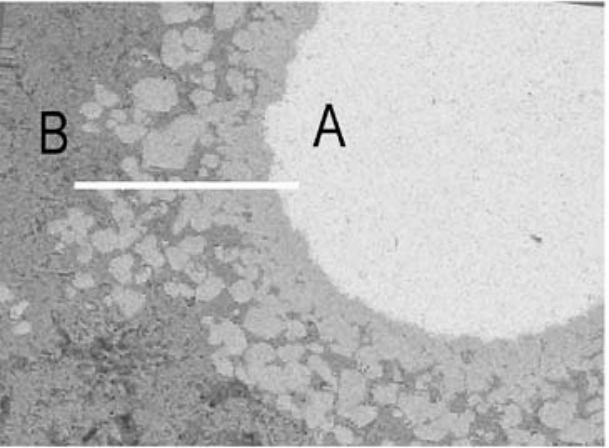

(a)

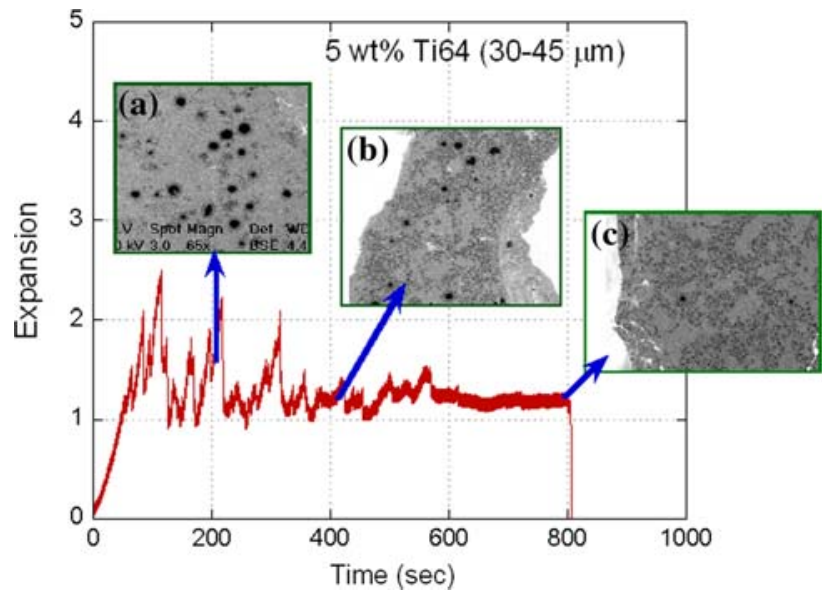

Fig. $14 \mathrm{SEM}$ images of $\mathrm{TiAl}_{3}$ particle developments in 30-45 $\mu \mathrm{m}$ (5 wt.\%) Ti64 particles added foamed compact samples at furnace holding times of a 208, b 497, and c 805 s

The foaming process is a relatively quick process and a maximum expansion is reached within $100 \mathrm{~s}$. It was argued that the measured maximum expansions were due to the rapid bursting of hydrogen in the initial foaming stage after the compact melted [12]. The initial slow-rate expansion in the expansion-time curves was due to the expansion of the mushy compact before the complete melting of the compact. After the melting, the compact showed a higher rate of expansion (Region 2 of Fig. 2a). Stanzick et al. [15] analyzed the foaming behavior of uniaxially compacted AlSi7 and thixocast AlSi6Cu4 foamable precursors using real-time X-ray radioscopy. The cell wall rupture time for both types of precursors was found to be around $50 \mathrm{~ms}$. The cell rapture occurred at cell wall thicknesses below $50 \mu \mathrm{m}$. A cell wall rupture time below $33 \mathrm{~ms}$ was further found in the external foaming of a $20 \mathrm{vol} \% \mathrm{SiC}(10 \mu \mathrm{m})$ particle-added $\mathrm{Al}$ melt by argon gas blowing [10, 11], proving again a fast cell wall rupture in a few milliseconds.
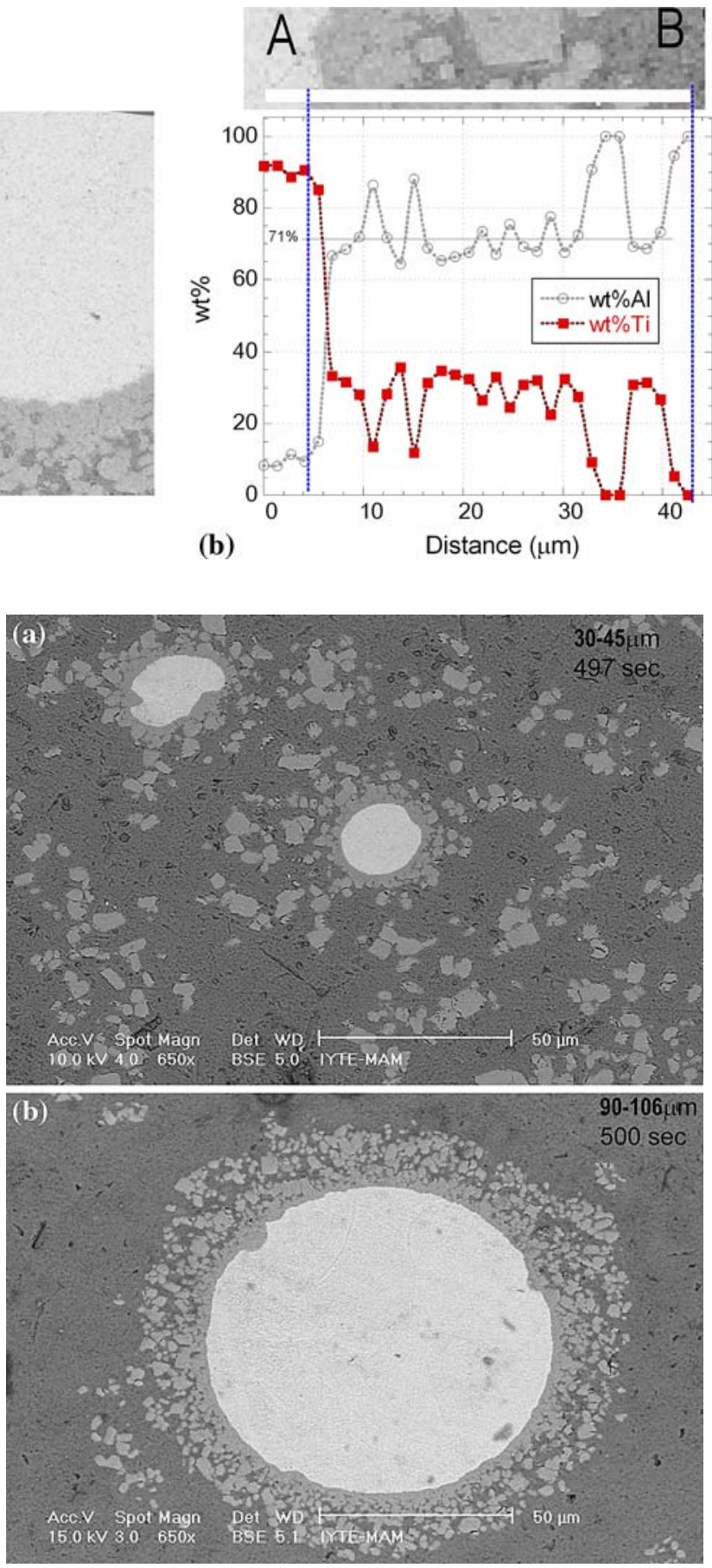

Fig. 15 SEM pictures of Ti64 particle-added foamed compacts (furnace holding time $500 \mathrm{~s}$ ) showing the reaction layer around the particles; a 30-45 $\mu \mathrm{m}$ and b $90-106 \mu \mathrm{m}$ particles

The rupture events were further shown to increase greatly with increasing foaming time after an incubation time of $106 \mathrm{~s}$, which is well accords with the present study, nearly corresponding to the maximum expansions. For the studied foams, the cell wall rupture events are therefore likely to become dominant in regions following the maximum expansions in the expansion-time graphs. 
Fig. 16 Magnified cell structures of foams of $\mathbf{a}$ and $\mathbf{b}$ $\mathrm{Al}$ and $\mathbf{c}$ and d 160-200 $\mu \mathrm{m}$ Ti64 Al compacts after about $200 \mathrm{~s}$ furnace holding time
Fig. 17 Ti64 particles in 160$200 \mu \mathrm{m}$ Ti64-Al foam after 200 s furnace holding time a cell edge and $\mathbf{b}$ cell wall
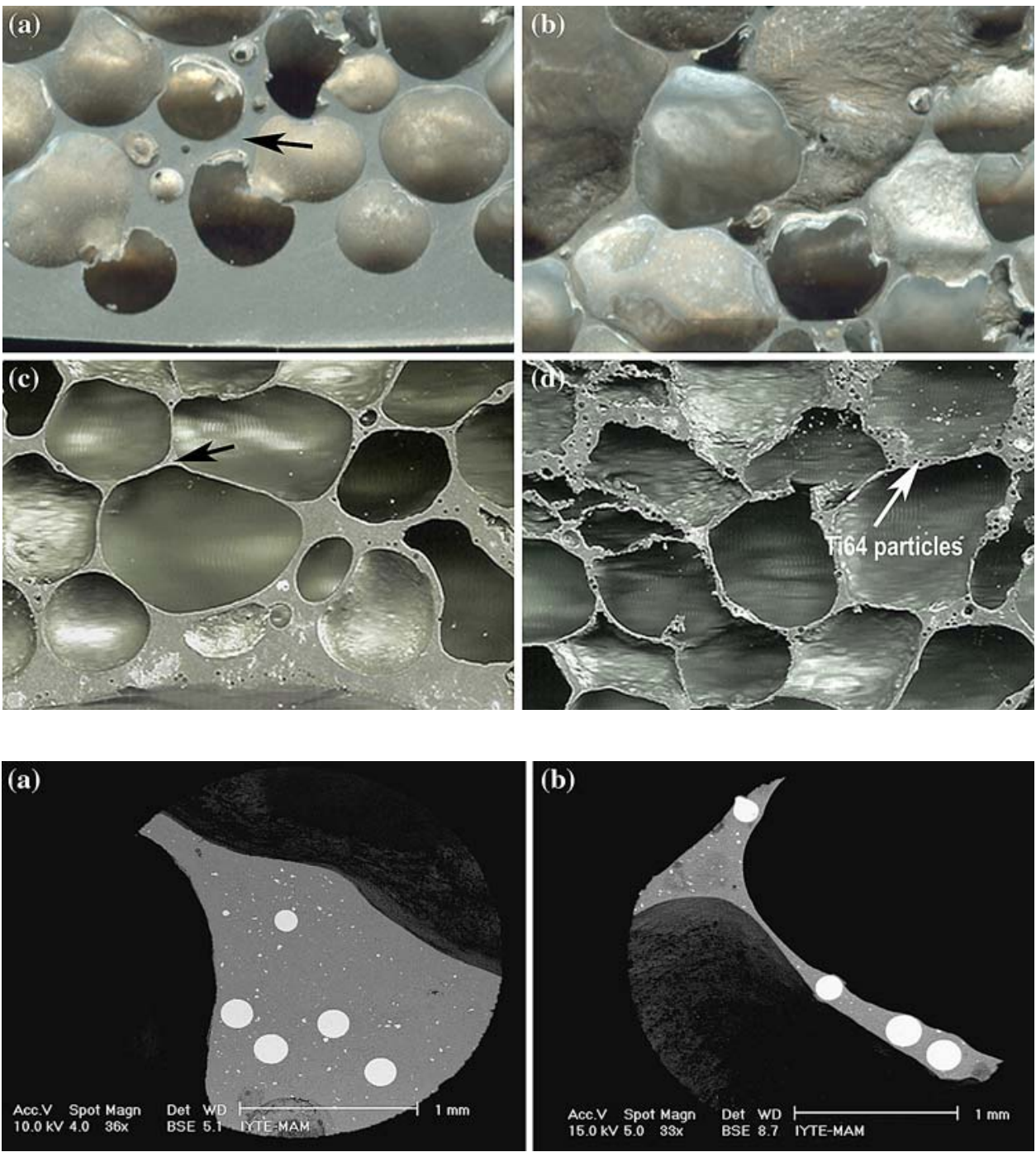

Although Ti64 particle additions of various sizes reduced the foamability of the compacts, it increased the foam stability. For the particle sizes of 160-200 $\mu \mathrm{m}$, the foams showed more homogenous cell size distribution and significant reductions in drainage. Haibel et al. [16] have recently analyzed five different stabilization mechanisms operative in the foaming of particle-added Al melts. In the first model, the wetted large particles on the cell wall reduce the pressure difference between cell wall and plateau border and capillary suction. In the second model, small particles sit at liquid/gas interface, which give rise to local menisci between adjacent particles, reducing the melt flow from the cell walls to the plateau borders. The third model, which has become popular recently, is based on the mechanical connection of the particles covering the opposite wall surfaces, which provides repulsive mechanical forces. The fourth model is based on the increased viscosity of the melt due to the presence of small particles within the cell walls, which immobilize the liquid metal flow. In the last model, the small particles located in cell walls and at the cell wall surfaces increase the viscosity of the melt and decrease the pressure difference between the cell walls and plateau borders. Based on the X-ray tomography analysis of the cell walls and the microscopic observations of particle distribution, the last model, comprising the particle covering the cell faces and increasing apparent viscosity of the melt, was proposed to be responsible for the foam stabilization. Based on the above foam stabilization models, the effects of Ti64 addition on the expansion and stability of Ti64-Al compacts will be discussed. The effects of average particle size on the maximum expansion and expansion values of $\mathrm{Al}$ compacts at constant particle weight percent (5 wt.\%) are shown in Fig. 18. On the same graph, the average accumulative surface area of the particles is also shown. At low average particle sizes and high cumulative particle surface areas, 


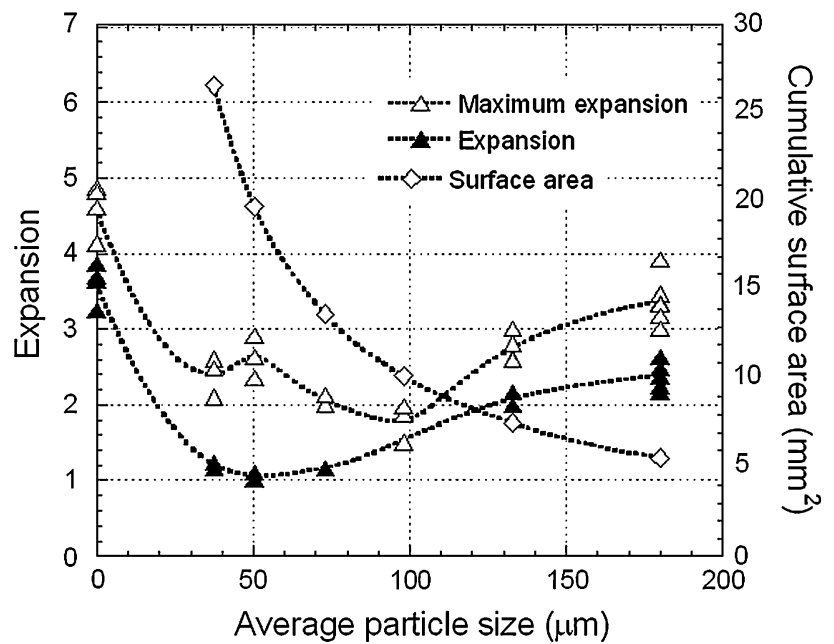

Fig. 18 Expansions and cumulative surface areas of Ti64 particles vs. average Ti64 particle size

the linear expansion and maximum expansion values of Ti64-Al compacts are relatively low, but increase with increasing average particle size after about $100 \mu \mathrm{m}$ and/or with decreasing cumulative particle surface area. Both the reaction product $\left(\mathrm{TiAl}_{3}\right)$ and Ti64 particles increase the apparent viscosity of the foaming compacts. At small particle sizes, due to higher surface area of the particles and higher rate of $\mathrm{TiAl}_{3}$ formation, the foam expansions are relatively low. At larger particle sizes, the lower surface area of the particles and the reduced amount of reaction product relatively increase the compact expansions. The stability of Ti64-Al compacts is therefore matched to the fourth model: increased viscosity of the melt due to the presence of particles in the cell walls. This has also been confirmed microscopically as no particles were found at the cell wall surfaces. Ti64 particles in the cell walls are further observed to form local menisci (Fig. 17b); therefore, the first model of the foam stabilization may also be effective in the stability of Ti64-Al foamed compacts. However, the numbers of these particles are low and this effect is merely seen in foams of large particles. The partially wetted particles are effective in preventing bursting of the cells by covering the surfaces of the cell walls, while in Ti64-Al foamed compacts, only oxide remnants of the powder particles or oxide particles formed during foaming may be found at liquid/gas interface. The initial powder used in the preparation of the powder compacts used for foaming experiments contains thin oxide films, which previously covered the surface of the metallic powder particles. The compaction process breaks the oxide layer skin. These thin oxide films are converted to broken oxide filaments with a size between 4 and $100 \mathrm{~nm}$ and an average of $20 \mathrm{~nm} \mathrm{[10].}$
The relative density of the compacts may have an important effect on the foam expansions. Low relative densities may lead to early escape of the gas, resulting in lower expansions. The average relative density of $\mathrm{Al}$ compacts is about $1 \%$ higher than those of Ti64-Al compacts (Table 1). The use of higher compaction pressures in Ti64-Al powder compaction resulted in lateral cracks in the compact. One sample was prepared through hot compaction $\left(350^{\circ} \mathrm{C}\right)$ with a relative density of $98 \%$. The foam structure and the expansion behavior of the hot consolidated powder compact were found to be similar to those of cold-consolidated compacts.

Several different studies however showed that the foaming behavior is also a function of foaming temperature $[12,17]$. At low foaming temperatures sufficient gas release for foaming did not occur, while foaming at high temperatures resulted in rapid bubble coalescence. The effect of foaming temperature, therefore, should be investigated on the foaming behavior of Ti64-Al foamed compacts. Other parameters that might affect the foamability include the volume fractions and Ti64 particle size. It was shown in this study that, at lower volume fractions of 30-45 $\mu \mathrm{m}$ particles, the foam expansion reached to the expansion values of $\mathrm{Al}$ compacts. The effect of particle volume fractions should therefore be further investigated through systematical microscopic studies. Currently the lowest particle size of Ti64 powder commercially available is in the range of $30 \mu \mathrm{m}$. The lower sizes of the powder may be obtained through ball milling and/or with the use of angular particles. The oxygen content of the starting powders should be determined to assess more accurately the effect of oxide skin remnants of the powder on the expansion and stability. This may help to differentiate the expansion and stability of powder compacts contributed merely by Ti64 addition. In addition, the size and the amount of the reaction product $\left(\mathrm{TiAl}_{3}\right)$ should be determined as a function of foaming temperature and furnace holding time. This may provide useful information about the variation of the melt viscosity with the amount of the reaction products, which may later be used in the optimization of the foaming of Al compacts with Ti64 particle addition.

\section{Conclusions}

The linear expansions of $30-200 \mu \mathrm{m}$ Ti64-Al powder compacts were measured to determine the effect of particle addition on the foaming of $\mathrm{Al}$ compacts. $\mathrm{Al}$ compacts without particle addition were also foamed. The linear expansion measurements showed good agreements with previous studies on similar compacts. The expansion of 5 wt.\% Ti64-Al compacts was relatively low at size ranges 
30-45, 45-56, and 56-90 $\mu \mathrm{m}$ and increased with increasing particle size until $160-200 \mu \mathrm{m}$ particle range. At highest particle size, Ti64-Al compacts showed expansion-time graphs very similar to Al compacts, but with lower expansion values. Foam expansions of 30-45 $\mu \mathrm{m}$ size Ti64-Al compacts with varying wt.\% of particles showed that when the wt.\% of particles was 1 or lower, the expansion behavior of the compacts became very similar to that of Al compact. Microscopic studies have clearly shown a reduced extent of foam drainage in Ti64-Al compacts. In the foaming of Ti64-Al powder compacts, the liquid $\mathrm{Al}$ reacted with Ti64 particles and formed $\mathrm{TiAl}_{3}$ particles. The reduced drainage and lower foam expansions in the foaming of Ti64-added compacts were discussed based on the foam stabilization models in the literature. The reduced foamability of the compacts with the small particle size of Ti64 addition was attributed to the relatively high viscosities due to the higher cumulative surface area of the particles and higher rate of $\mathrm{TiAl}_{3}$ formation. In comparison with Al compacts, 160-200 $\mu \mathrm{m}$ Ti64-Al compacts showed reduced number of cells and cell sizes, showing a more stable foaming process.

Acknowledgements The authors would like to thank the Scientific and Technical Council of Turkey (TUBITAK) for the grant \#106M186.

\section{References}

1. Jin I, Kenny LD, Sang H (1990) Method of producing lightweight foamed metal. US Patent 4973358

2. Leitlmeier D, Degischer HP, Flankl HJ (2002) Adv Eng Mater 4:735

3. Wang DQ, Shi ZY (2003) Mater Sci Eng A 361:45

4. Song ZL, Ma LQ, Wu ZJ, He DP (2000) J Mater Sci 35:15. doi: 10.1023/A:1004715926692

5. Banhart J (2000) JOM-J Miner Met Mater Soc 52:22

6. Asavavisithchai S, Kennedy AR (2006) J Colloid Interf Sci 297:715

7. Kennedy AR, Asavavisitchai S (2004) Scripta Mater 50:115

8. Kennedy AR, Asavavisithchai S (2004) Adv Eng Mater 6:400

9. Guden M, Yuksel S (2006) J Mater Sci 41:4075. doi: 10.1007/s10853-006-7645-x

10. Babcsan N, Leitimeier D, Banhart JB (2005) Colloid Surf A: Physicochem Eng Asp 261:123

11. Babcsan N, Moreno FG, Banhart J (2007) Colloid Surf A: Physicochem Eng Asp 309:254

12. Duarte I, Banhart J (2000) Acta Mater 48:2349

13. Duarte I, Mascarenhas J, Ferreira A, Banhart J (2002) Adv Mater Forum I 230-232:96

14. Asavavisithchai S, Kennedy AR (2006) Adv Eng Mater 8:810

15. Stanzick H, Klenke J, Danilkin S, Banhart J (2002) Appl Phys A: Mater Sci Process 74:S1118

16. Haibel A,Rack A, Banhart J (2006) Appl Phys Lett 89

17. Yu CJ, Eifert HH, Banhart J, Baumeister J (1998) Adv Mater Process 154:45 